\title{
Fluorine-doped tin oxide films by spray pyrolysis using vacuum within nozzle
}

\section{Filmes de óxido de estanho com flúor produzidos por pulverização pirolítica produzindo vácuo no pulverizador}

Francisco Marcone Lima¹, José Hugo de Aguiar Sousa², Paulo Herbert França Maia Júnior ${ }^{1}$, Álvaro Neuton de Araújo Silva", Aline Cosmo de Sena 1 , Francisco Nivaldo Aguiar Freire ${ }^{1}$, Ana Fabíola Leite Almeida ${ }^{1}$

\begin{abstract}
Fluoride-doped tin oxide films on glass substrate were prepared from $\mathrm{NH}_{4} \mathrm{~F}$-doped $\mathrm{SnCl}_{2}$ precursor by spray pyrolysis with ceramic heater as heat source, which was inserted inside the reactor and created a vacuum within nozzle. The films were characterized by scanning electron microscopy, UV-Vis spectroscopy, measurement of electrical resistance and X-ray diffraction. The results showed that the fluoride-doped tin oxide films demonstrate potential as materials for photovoltaic applications.
\end{abstract}

Keywords: Fluorine-doped tin oxide, Spray pyrolysis, Vacuum.

\section{RESUMO}

Filmes de óxido de estanho com flúor, depositados sobre substratos transparentes, foram preparados a partir de uma solução contendo uma mistura de $\mathrm{NH}_{4} \mathrm{~F}$ e $\mathrm{SnCl}_{2}$. Uma resistência cerâmica, inserida em um forno, foi usada como fonte de calor. A deposição foi feita por meio da técnica pulverização pirolítica, com vácuo sendo gerado no bico de pulverização. A caracterização das amostras foi feita com auxílio de microscopia eletrônica de varredura, espectroscopia UV-vis, resistência elétrica e difração de raios-X. Os resultados indicam a aplicabilidade do material para a aérea fotovoltaica.

Palavras-chave: Óxido de estanho com flúor: Pulverização pirolítica: Vácuo. 


\section{INTRODUCTION}

In the field of advanced materials, transparent conductive oxides (TCOs) have been widely investigated to explore their unusual properties for a variety of applications ${ }^{(1-4)}$. The fluoridedoped tin oxide (FTO) is an n-type wide band gap semiconductor and has been the leading candidate among the extensively investigated $\mathrm{TCOs}^{(5-9)}$. FTO semiconductors have applications as transparent conductors, heat reflectors, oxide matrix in the dyesensitized solar cells $s^{(1,2,6)}$.

For the preparation of FTO electrodes, the sol-gel method, chemical vapor deposition and spray pyrolysis techniques have been reported ${ }^{(10-15)}$. Spray pyrolysis involves spraying a solution containing chemical species and a heated substrate ${ }^{(14,15)}$. The heated substrate provides the thermal energy for thermal decomposition and subsequent recombination of the constituent species, and followed by sintering and recrystallization of the clusters of crystallites on substrate surface ${ }^{(7,13)}$.

The spray pyrolysis of $\mathrm{SnCl}_{4}$ solution for obtaining TCOs was performed as early as $1910^{(13)}$. This work presents the spray pyrolysis of $\mathrm{SnCl}_{2}$ complexed with $\mathrm{NH} 4 \mathrm{~F}$ in a mixture of water and $\mathrm{HCl}$. The ceramic heater as heat source was enclosed in a furnace chamber. The as-prepared product was characterized by X-ray diffraction (XRD), bipolar measurement of electrical resistance, scanning electron microscopy (SEM) and ultravioletvisible (UV-vis) spectroscopy.

\section{EXPERIMENTAL}

Fluoride-doped tin oxide (FTO) film was deposited on a microscope slide glass at $600^{\circ} \mathrm{C}$ by spray pyrolysis. Solution of tin chloride $\left(\mathrm{SnCl}_{2} \cdot 2 \mathrm{H}_{2} \mathrm{O}, 98 \%\right.$, Dinâmica) in water and hydrochloric acid ( $\mathrm{HCl}, 37 \%$, Synth) with ammonium fluoride $\left(\mathrm{NH}_{4} \mathrm{~F}, 98 \%\right.$, Vetec) as a dopant, as spray solution or chemical solution. FTO electrodes were prepared under the following conditions: the furnace with ceramic heater (ohmic heater), glass substrates temperature at $600{ }^{\circ} \mathrm{C}$, solution concentration (ratio of acid and water were 1:1; tin chloride-mass and acid-volume 1:2.5 and $\mathrm{NH}_{4} \mathrm{~F}: \mathrm{SnCl}_{2}$ mass ratio were 0.165:1).

Firstly the ceramic heater (Higher, 220V/500W) was enclosed into furnace chamber (EDG F-1800), and the chamber temperature of $600{ }^{\circ} \mathrm{C}$ was kept by a furnace's feedback circuit. The chemical solution was atomized into a spray of fine droplets by a spray nozzle (APREX's alfa 4) with the help of a carrier gas (air) fed into of the spray nozzle from air compressor (SHULZ's Twister).

The initial condition for the ceramic support substrate (surrounding I) was room pressure and temperature. The substrate was placed inside the furnace chamber and the temperature was kept at $600{ }^{\circ} \mathrm{C}$ (surrounding II). The solution was atomized over the hot substrate. Thus the process was not continuous, but the substrate was maintained into the chamber between the coating depositions in order to minimize heat losses.
The as-prepared product was characterized by XRD with $2 \theta$ ranging from $10^{\circ}$ to $100^{\circ}$, using an XPert Pro MPD - Panalytical $\mathrm{X}$-ray diffractometer (Co-Kal radiation). The morphology and thickness were analyzed by SEM using a PHILIPS XL-30 scanning electron microscope, employing an accelerating voltage of $20 \mathrm{kV}$. The transmittances of the FTO electrodes were tested by an Ocean optics USB 2000+ spectrophotometer, in the range of $300 \mathrm{~nm}$ to $900 \mathrm{~nm}$. Their electrical resistance was tested with a PC Link VA18B multimeter.

\section{RESULTS AND DISCUSSION}

The carrier gas and precursor solution mixture and the size distribution of droplets are dependent significantly on the geometry of the nozzle ${ }^{(13)}$. The spray nozzle works by creating a vacuum inside the nozzle, absorbing the solution. This system does not depend on the gravity to work, and it allows for the chemical solution to be atomized into a spray of fine droplets.

The spray pyrolysis involves a thermally stimulated chemical reaction between clusters of liquid/vapor atoms ${ }^{(13)}$. Thus to obtain the corresponding fluoride-doped tin oxide films an acidic solution of tin chloride and ammonium fluoride were sprayed on hot substrate (at $600{ }^{\circ} \mathrm{C}$ ) with air as carrier gas.

The decomposition of the precursor solution to initiate film growth is strongly dependent of the temperature ${ }^{(13)}$. Also, excess solvent and by-products escape in the vapor phase ${ }^{(5,12,13)}$. Since inside the chamber atmosphere there is corrosive agents due to the presence of $\mathrm{HCl}, \mathrm{NH}_{3}$ and other by-products, the use of the ceramic heater employed in the present study is justified. The ceramic heater is basically a resistance inserted in a ceramic plate that protects it from oxidation.

The substrate (surrounding I) experiences a change temperature change when placed in the furnace chamber and as result, the substrate begins to change its condition towards the temperature of $600{ }^{\circ} \mathrm{C}$ in order to be in equilibrium with surroundings II. Though the sprayed droplets reaching the hot substrate surface forms desired product but, it causes a temperature drop of the substrate. Thus the substrate temperature of $600{ }^{\circ} \mathrm{C}$ is restored by keeping the substrate inside the furnace between the coating depositions.

Oxide films are dependent on relatively complex reactions and stoichiometry that not match of an oxide bulk ${ }^{(13)}$. In sprayed tin oxide films, the presence of $\mathrm{Sn}^{+2}$ species and oxygen vacancies have been observed in pure tin oxide films ${ }^{(1,13)}$. They are present in form $\mathrm{Sn}^{4+}{ }_{(1-\delta)} \mathrm{Sn}_{(1-\delta)}^{2+} \mathrm{O}_{(2-\delta)}^{2-}$ and in general are showed as $\mathrm{SnOx}^{(13)}$.

Deviation of stoichiometry in tin oxide ( $\mathrm{SnOx}$ ) is controlled by water content in the chemical solution and also the presence of $\mathrm{HCl}$ in the solution reduces the chlorine concentration into the tin oxide films ${ }^{(13)}$. Thus, in tin oxide films from tin(II) salt, the presence of $\mathrm{Sn}^{+4}$ may be associated with the conversion of $\mathrm{Sn}^{+2}$ to $\mathrm{Sn}^{+4}$ species from of thermally stimulated chemical reaction between clusters of $\mathrm{Sn}^{+2}$ /oxygen atoms. 
The water molecules provide oxygen, however the oxygen concentration is affected by the rate of cooling of the films after the spray due to the adsorption of oxygen ${ }^{(13)}$. The oxygen deficiency and dopant presence into films increase the electric conductivity of them ${ }^{(14,15)}$. Furthermore, the number of oxygen-ion vacancies is equal to number of $\mathrm{Sn}^{+2}$ species content into films, which form a donor band in tin oxide ${ }^{(13)}$.

The transparency, electrical resistance, structural and morphology of sprayed tin oxide films are dependent on deposition conditions, in particular, substrate temperature, chemical solution, dopants, and postdeposition treatments ${ }^{(1,13,15)}$. Moreover, the electrical conductivity of tin oxide films is attributed to presence of multivalency tin species, oxygen deficiency and presence of dopant, for example, F impurity ${ }^{(13)}$.

As $\mathrm{F}$ species has a low vapor pressure and forms a volatile gaseous product, so a F:Sn atomic ratio is not same as in solution yields films containing less than a few percent of $\mathrm{F}$ species ${ }^{(13)}$. Thus, a F:Sn atomic ratio de 1.0 in solution were used for F-doped tin oxide films made by spray pyrolysis with ceramic heater

In the present study, F-doped tin oxide films made by spray pyrolysis with ceramic heater have 6-9 $\Omega / \square$ electrical resistance and average transmittance of $70 \%$ into high-visible and low-infrared regions. The values are influenced by the parameters mentioned above. Therefore, the electrical resistance and transparency could be improved by varying the cited previously parameters.

The following conditions were adopted: the substrate temperature of $600{ }^{\circ} \mathrm{C}$, tin(II) anf $\mathrm{F}$ salts dispersed in water and acid solvents, ceramic heart into furnace's chamber, air as carrier gas, not-continuous deposition process and cooling of the films. Figure 1 shows the XRD diffractogram for as-sprayed products on glass substrate (F-doped tin oxide films).

The film (Fig. 1) was found to be of type tetragonal rutile structure, which matches with JCPDS card, no. 01-077-0452. F-doped tin oxide films exhibit rutile structure such as a tin oxide bulk ${ }^{(13)}$. XDR scan (Fig. 1) from the as-synthesized products like-rutile structure tin oxide with tetragonal lattice constant $\mathrm{a}=\mathrm{b}=4.76 \AA$ and $\mathrm{c}=3.20 \AA$ (JCPDS card, no. 01-077-0452).
In general, the dopants or impurity are incorporated substantially or into oxygen ions vacancies ${ }^{(13)}$. In case of the $\mathrm{F}$ species, $\mathrm{F}$ atomic ray like with $\mathrm{O}$ atomic ray ${ }^{(15)}$, $\mathrm{F}$ preferencial incorporation into oxygen ions vacancies ${ }^{(13)}$. The presence of $\mathrm{F}$ species into tin oxide films like-occur (200) orientation ${ }^{(2,4)}$. As the film (Fig. 1) contains the characteristic $\mathrm{SnO}_{2}$ peaks only, it shows that $\mathrm{F}$ species acts as an impurity.

Presence of peaks with weak intensities such as (110), (101) (220), (310), (301) and (321) have been detected ${ }^{(15)}$. It is perceptible that the F-doped tin oxide film (Fig.1) grow not only along (200) planes as also along of (110), (211), (301) and (310). The solution concentration decides the preferred orientation of growing grains ${ }^{(15)}$. The lower $\mathrm{F}$ doping concentration increased the intensity of the (200) plane $e^{(2,4,15)}$. The similar conclusion should be drawn for the other planes.

As result of the growth process and consequent microstructure, sprayed films are generally strongly adherent on substrate, mechanically hard, rough surface morphology and stable with temperature up to the spray temperature ${ }^{(13)}$. Figure 2 shows the morphology of F-doped tin oxide film with thickness of $3.8 \mu \mathrm{m}$. The surface like-has submicron- to micron-size grains scattered on a rough background.

The formation of F-doped $\mathrm{SnO}_{2}$ film generates by-pro$\operatorname{ducts}^{(5,12,13,15)}$. When the formation of F-doped $\mathrm{SnO}_{2}$ film is from

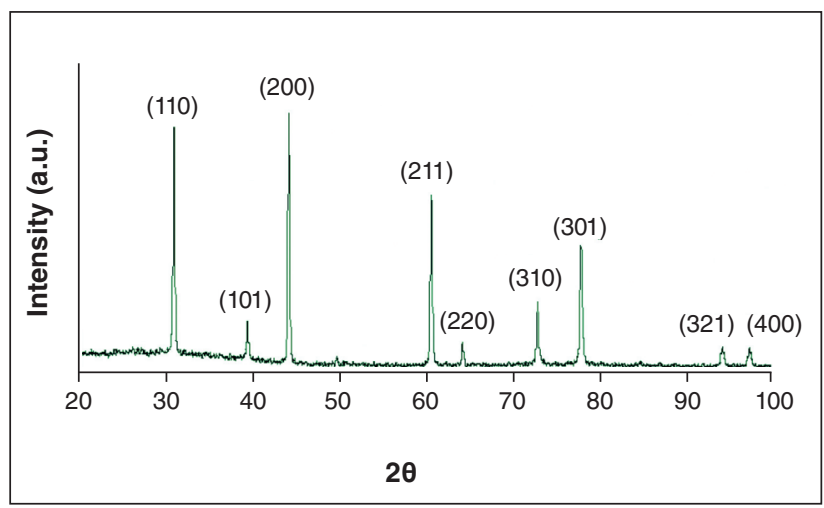

Figure 1:XRD scan from as-sprayed product.

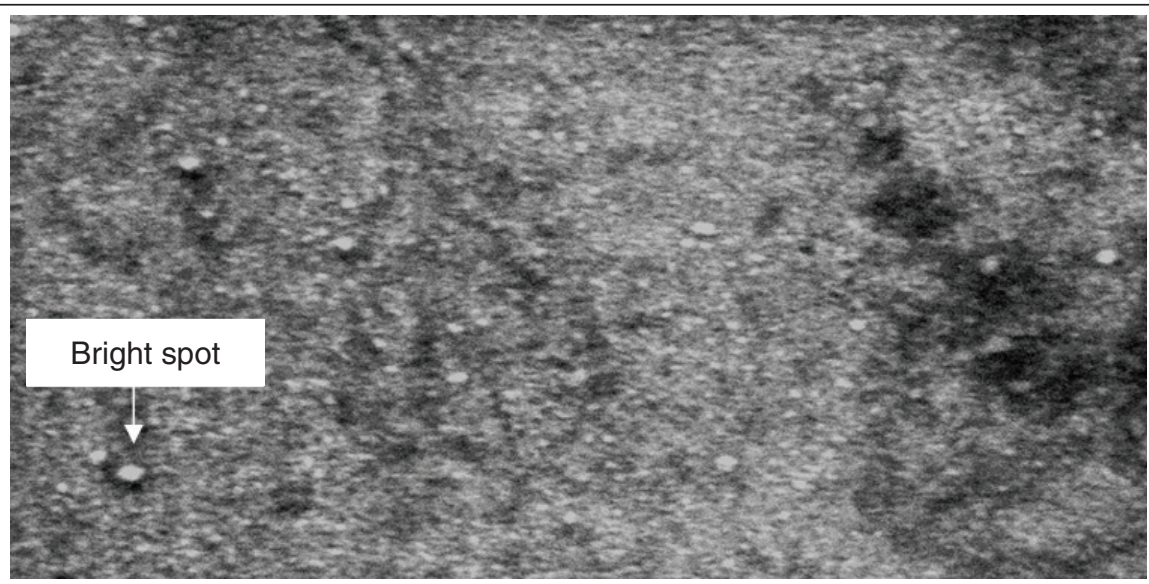

Figure 2: SEM micrograph of surface of the F-doped tin oxide film (scale: $10 \mu \mathrm{m}$ ) 
a $\mathrm{SnCl}_{2}$ solution occur the formation and decomposition transitory compounds such as $\mathrm{SnO}, \mathrm{HF}, \mathrm{NH}_{3}, \mathrm{HCl}$ and $\mathrm{SnF}_{4}{ }^{(15)}$. Also, the bright spots on surface of F-doped $\mathrm{SnO}_{2}$ film are unknown non-conductive impurities (by-products) included during the process of preparation of the films ${ }^{(14)}$.

The SEM micrograph (Fig. 2) showed the presence of bright spots on surface of F-doped $\mathrm{SnO}_{2}$ film. Possibly, it not decomposition of some transitory compounds was reflected in F-doped $\mathrm{SnO}_{2}$ film as observed in SEM micrograph as it lead to the bright spots. They are distributed on the entire surface and the morphology them is of grains without similar size and with circle-like shape.

\section{CONCLUSIONS}

In spray pyrolysis, the important parameter for the microstructure of sprayed F-doped $\mathrm{SnO}_{2}$ films is substrate temperature. It is presumably because it like-avoid the growth kinetics of the films to obtain the corresponding oxide films from salts. Also, the microstructure like-depend under others spray parameters, as such type of salts and dopants, geometry of the gas and liquid nozzles. Therefore, the optical, morphology, structural and electrical properties of sprayed oxide films are dependent of under deposition conditions.

The electrical and optical proprieties are must interest in largearea sprayed films, due its applications in solar energy, particularly, photovoltaic solar energy. The results showed that the fluoridedoped tin oxide films on glass substrate demonstrate potential as materials for photovoltaic applications.

\section{ACKNOWLEDGEMENTS}

The authors thank the UFC (Universidade Federal do Ceará), CAPES (Coordenação de Aperfeiçoamento de Pessoal de Nível Superior), $\mathrm{CNPq}$ (Conselho Nacional de Desenvolvimento Científico e Tecnológico), FUNCAP (Fundação Cearense de Apoio ao Desenvolvimento Científico e Tecnológico), Laboratório de Raios-X,
LACAM (Laboratório de Caracterização de Materiais), and LAFFER (Laboratório de Filmes Finos em Energias Renováveis) located in the UFC, and the employees Valdi de Matos de Almeida Júnior and Juliana Arruda Lima.

\section{REFERENCES}

1. RIVEROS, R.; ROMERO, E.; GORDILLO, G., Brazilian Journal of Physics, 36 (2006) 1042

2. KWON, H.; HAN, D.; KWAK, D.; YOUL-MOON, S., Current Applied Physics 10 (2010) S172.

3. GREEN, A. A.; HERSAM, M. C., Nanoletters 8 (2008) 1417.

4. KUANTAMA, E.; HAN, D.; SUNG, Y.; SONG,J.; HAN, C., Thin Solid Films 517 (2009) 4211.

5. RIZZATO, A. P.; PULCINELLI, S. H.; SANTILLI, C.V., Química Nova $21(1998) 510$

6. GRÄTZEL, M., Journal of Photochemistry and Photobiology C: Photochemistry Reviews 4 (2003) 145

7. BERTUS, L.M.; ENESCA, A.; DUTA, A., Thin Solid Films 520 (2012) 4282.

8. VARELA, J. A.; PERAZOLLI, L.A.; CERRI, J. A.; LeITE, E. R.; LONGO, E., Cerâmica 47 (2001) 1.

9. SHI, L.; Lin, H., Langmuir 26 (2010) 18718.

10. BREWER, S. H.; FRANZEN, S., Journal of Alloys and Compounds 338 (2002) 73

11. KUMAR, V.; GOVIND, A.; NAGARAJAN, R., Inorganic Chemistry $50(2011) 5637$

12. CARDOSO, W.S.; DE PAOLI, M. A., Química Nova 28 (2005) 345.

13. HASS, G.; FRANCOMBE, M. A.; VOSSEN, J. L., Physics of Thin Films, twelfth volume, London: Academic Press, 1982.

14. KRISHNAKUMAR, R.; LAKSHMANAN, A. S.; RAMAKRISHNAN, K.; SUBRAMANIAN, V.; SURYANARAYANA, C. V., Bulletin of Electrochemistry 2 (1985) 185

15. ELANGOVAN, E.; RAMAMURTHI, E. K., Applied Surface Science $249(2005) 183$ 